\section{NRTSC}

NUCLEAR REACTOR TECHNOLOGY

AND SCIENTIFIC COMPUTATIONS
Keywords

Reactor Materials Program Moderator

Shield Water

Ratacior

Corrosion $\operatorname{kiscc}$ Stainless Stoel

Aluminum PTEFM CAMEL

Rotention. Permanent

\title{
RESULTS AND RECOMMENDATIONS FROM THE REACTOR CHEMISTRY AND CORROSION TASKS OF THE REACTOR MATERIALS PROGRAM (U) \\ Task \#89-023-G-1
}

\section{$(B \mathbf{B})$}

E.W. Baumann Rubxumenn

R. S. Ondrejcin R.S. Ondije.

ISSUED: November, 1990

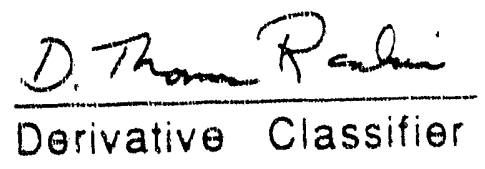

SRL SAVANNAH RIVER LABORATORY, AIKEN, SC 29808 Westinghouse Savannah River Company Prepared for the U.S. Departiment of Energy under Contract 
PROJECI: Reactor Materials Program

DOCUMENT: WSRC-TR-90-477

TITLE:

TASK:
Results and Recommendations from the Reactor Chemistry and Corrosion Tasks of the Reactor Materials Program (U)

Task \#89-023-G-1, Measure Effect of Moderator Chernistry on Stress Corrosion of Sensitized and of Irradiated Stainless Steel

APPROVALS

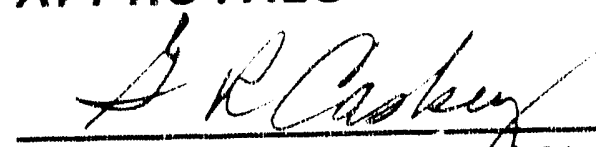

DATE: $\quad 1,6-90$

G. R. Caskey, TECHNLCAL REVIEWER MATERIALS TECHNOLOGY

D. Th er Rabin

DATE: $11-7-90$

D. T. Rankin, MANAGER

MATERIALS TECHNOLOGY

Ans he

DATE: 11.9 .92

J. M. Stone, MANAGER

MATERIALS TECHNOLOGY

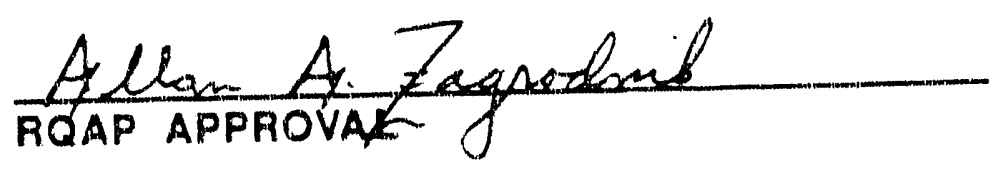

DATE: $\leadsto-27-20$ 
1.0 INTRODUCTION

2.) SUMMARY \& RECOMMENDATIONS

3.0 DISCUSSION

3.1 System Description

3.1.1 Primary System

3.1 .2 Shield Systems

3.1.3 History

3.2 Reactor Moderator Chemistry

3.1.2 Implementation of $\mathrm{pD}$ Control

3.2.2 Chemical Aspests of $\mathrm{pD}$ Control

3.2.3 Chemistry Role in Stainless Steel Corrosion

3.2.4 Chemistry Role in Aluminum Corrosion

3.3 Results from the Reactor Materials Program

3.3.1 Background

3.3.2 Task 6: Aqueous Environment

3.3.3 Task 7: Corrosion

3.3.3.1 CERT Tests

3.3.3.2 Crack Growth Tests

3.3.4 Task 10: Electrochemical Potential

3.4 Application of Results

3.4.1 General Comments

3.4 .2 Moderator

3.4.2.1 pD Control

3.4.2.2 pD Limits

3.4.2.3 Oxygen Control

3.4.2.4 Radiolysis

3.4.2.5 Impurity Control

3.4.2.6 Mode of Reactor Operation

\subsubsection{Shield Water}

\section{REFERENCES}

TABLE 1 Principal Dissolved Constituents in Moderator

TABLE2 Dissolved Constituents in Thernal Shield Water

TABLE 3 Tasks of the Reactor Materiais Program

TABLE4 Concertration Rangetis of Independent Variables

TABLE5 Evaluation of Moderator \& Shield Water Conditions from CERT Tests

TABLE 6 Synthetic Moderator Environments for Crack Growth Tests

TABLE 7 Technical Standards and Operating Limits

TABLE 8 Sampling Frequencies

FIGURE 1 105-K Reactor Complex 


\section{WESTINGHOUSE SAVANNAH RIVER COMPANY INTER-OFFICE MEMORANDUM}

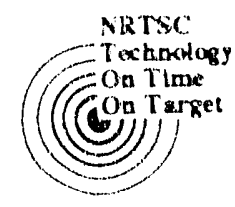

WSRC-TR-90)-477

November 1,1990

TO.

I. D. SPENCER, 773-A

FROM:

E. W. BAUMANN, 773-41A/R. S. ONDREJCIN, 773-41A

\section{RESULTS AND RECOMMENDATIONS FROM THE REACTOR CHEMISTRY AND CORROSYON TASKS OF THE REACTOR MATERIALS PROGRAM (U)}

\subsection{INTRODUCTION}

Production reactors at the Savannah River Site (SRS) have operated successfully for over 30 years. Throughoul the operating history, corrosion of both the aluminum clad assemblies and the stainless steel pressure boundary has occurred. The moderator chemistry must therefore be optimized to mitigate corrosion of both systems. The corrosion of the stainless steel materials of the pressure boundary by stress corrosion cracking haye been confined to localized regions. The only known limitation to reactor service life is stress corrosion cracking of Type 304 stainless steel in portions of the primary components that cannot readily be repaired or replaced, such as the reactor tank or the thermal shields.

Within the general context of extended service life, the Reactor Materials Program was initiated in 1984. This comprehensive program addressed material performance in SRS reactor tanks and the primary coolant or Process Water System (PWS) piping. Three of the eleven tasks concerned moderator quality and corrosion mitigation.'

Definition and control of the stainless steel aqueous environment is a key factor in corrosion mitigation. The unique chernistry of the SRS PWS, which was designed to minimize corrosion of both stainless steel and aluminum, differs from the primary coolant chemistry of power reactors, which has been extensively evaluated for corrosive properties. The Reactor Materials Program systematically investigated the SRS environment and its effect on crack initiation and propagation in stainless sicel, with the objective of improving this environment.

The purpose of this report is 10 summarize the contributions of Tasks 6,7 and 10 of the Reactor Materials Program to the understanding and control of moderator quality and its relationship to mitigation of stress corrosion cracking. 


\subsection{SUMMARY AND RECOMMENDATIONS}

This report extracts the findings of the three tasks of the Reactor Materials Program that provide the basis for mederator quality improvement. The three tasks are:

Task 6: 10 analyze impurities in reactor aqueous streams 10 provide data for subsequent corrosion testing.

Task 7: to determine the effect of SRS environment and operating conditions on crack initiation and crack growth rates through Constant Extension Rate Tensile (CERT) tesis and crack growth experiments.

Task 10: to measure electrochemical potentials of stainless steel and platinum in the uncooled moderator of an SRS reactor during all phases of reactor operation.

The three tasks produced the following:

- a comprehensive view of moderator and shield water chemistry, based on offine analysis

- initiation of the concept of the value of online analysis, providing the groundwork for future online instrumentation for the reactor (although the purchased, custom design online analyzer was never installed)

- identification of temperature, chloride, sulfate, and the presence of peroxide as contributors to crack initiation and growth by IGSCC

- a mathematical relationship that permits prediction of the effect of varying these contributions for optimization

- a range of crack growth rates that agrees with rates measured by ultrasonic testing and laboratory data. The rates show wide variability and incremental increases with perturbations such as temperature changes.

- confirmation of the expected high electrochemical potentials of stainless steel in the reactor system because of the nitric acid-hydrogen peroxide chemistry of reactor moderator.

Recommendations for maintaining/improving moderator and shield water quality in SRS systems are derived and discussed. The following recommendations are made:

\section{For Moderator:}

- that no changes in the fundamental operation with nitric acid and excess oxygen be made

- that updated $\mathrm{pH}$ limits in Table 7 remain unchanged

- that reliable online monitors for oxygen be maintained, and that the minimum oxygen concentration necessary to ensure nitrate stability be determined experimentally during reactor operation

- that extraneous dissolved impurities, beyond the nitric acid and oxygen needed for $\mathrm{pD}$ control be eliminated

- that chloride and sulfate concentrations be reduced to 2 and $7 \mathrm{ppb}^{* *}$ respectively

* Intergranular Stress Corrosion Cracking

* parts per billion; micrograms per liter. 
- that ion exchange resins and praclices be reevaluated

- that potential sources of chloride and sulfate, such as filter and gasket materials. be replaced with lower source malerials where possible

- that sampling frequency be increased as practical; in particular, during periods of charge and discharge when the system can receive impurities from outside sources, sampling should be increased to once a day

- that additional online sensors, such as for chloride and sulfate, be installed; and that ultimately a second generation multipurpose online analyzer be evaluated and installed

- that the beneficial effect of reduced operating temperature in mitigating IGSCC be recognized

- that during reactor operation, efforis be made to reduce reactor scrams or other rapid thermal or load changes.

For Shield Water:

- that shield water be deionized to lower the chloride ion concentration to 5 ppb. and sulfate to $7 \mathrm{ppb}$.

\subsection{DISCUSSION}

\subsection{System Description}

\subsubsection{Primary System}

The primary system of the SRS reactors consists of a stainless steel tank with six heat exchanger loops symmetrically placed around the tank. The sketch in Figure I shows one of these loops. The primary system is made from Type 304 Stainless Sieel. Within the tank are aluminum-clad fuel and target assemblies plus ancillary aluminum fittings.

The system is filled with heavy water, which functions as coolant and neutron moderator as it is recirculated through the loops during reactor operation. ${ }^{2}$ The primary system is a closed system because of the need to maintain isotopic purity and to conserve the heavy water. One of the six loops contains filters and mixed-bed ion exchangers to maintain moderator quality. This deionization loop is included in Figure 1. The temperature of the moderator in the primary system has historically been from -35 to $\sim 105^{\circ} \mathrm{C}$.

Moderator quality for control of corrosion in the primary system must address the effect of the aqueous environment not only on stainless steel but also on the aluminum in the system. Table 1 gives the principal dissolved constituents in the moderator, their sources and their removal mechanisms.

\section{1 .2 Shield Systems}

In addition to the primary systern, the shield water systems in the reactors comprise another area where prevention of IGSCC is important to reactor service life. The thermal shields are located inside the concrete biological shield and would be very difficult to repair or replace. Figure 1 shows the location of the top, bottom, and thermal shields that surround the reactor lank. The primary concern about the 
chemistry of the shield water systems is prevention of corrosion of the shielding structure

The shield systems are made from Type 304 Stainless Steel. The top and bottom shicks contain stainless steel Raschig rings; the thermal shields contain "Duriron" grids which, like the Raschig rings, give efficient shielding and can be readily cooled. ${ }^{3,4}$

Each shield system is filled with light water, which is circulated from the shiclds through heal exchangers. The allowable temperalure range is $55-65^{\circ} \mathrm{C}$ at full power. 5 This temperature is maintained at full reactor power to prevent overstressing the $T$-weld on the bottom of the tank due to themal stresses caused by the difference in moderator and shield water temperature. The stress limit on the welds is set at 28,000 psi. ${ }^{6}$ The water is purged and replaced with deionized water periodically to maintain the conductivity and $\mathrm{pH}$ within specified limits. The ionic content of the thermal shields is not routinely determined. Special analyses. summarized in Table 2, showed that the shield water is much more impure than the moderator and that the composition varies.

\subsubsection{Histery}

The importance of moderator quality in controlling corrosion of the stainless steel lank and piping of the reactors has always been recognized. 8 From the initial startup of the reactors in the mid-1950's until the late 1950's moderator was fully deionized and bulk moderator conductivity was $<0.2 \mu \mathrm{S} / \mathrm{cm}^{*}$. The two major known nonradioactive impurities were deuterium gas (primarily from aluminum corrosion) and deuterium peroxide.

The importance of moderator quality in controlling corrosion of aluminum as well as stainless steel became apparent in the late $1950^{\prime} \mathrm{s}$. Shortly after larger pumps were installed and the fuel assemblics were operated at substantially higher surface temperatures, the moderator in all reactors became turbid. The turbidity was caused by very fine particles of hydrated aluminum oxide that sloughed off the fuel assemblies. The turbidity caused reduced visibility, pluggage of instrument lines, and carryover of radioactivity into the disassembly basins. The turbidity problem was solved by the institution of "pD* control". in which the moderator was slightly acidified by addition of nitric acid. 8 Turbidity is also reduced by use of distillation columns.

${ }^{*} \mu \mathrm{S} / \mathrm{cm}=$ microSiemens per centimeter, the unit of conductivity measurement: $\mu S / \mathrm{cm}$ is equivalent to micromhos $/ \mathrm{cm}$, the unit used in SRS reactor operation and procedures.

$*{ }_{\mathrm{p}} \mathrm{D}=-\log \left[\mathrm{D}^{+}\right]$. 


\subsection{Reactor Moderator Chemistry}

\section{2 .1 Linglementation of oD control ${ }^{8}$}

Operation with $\mathrm{pD}$ control consists of maintaining the moderator approximately 10 $\mu$ molar in nitric acid, corresponding to the $\mathrm{pD}$ limits of 5.0 to $5.2 .^{9}$ Because the acid is continually removed by the deionizers, nitric acid is added intermittently. $\mathrm{pH}(\mathrm{pD})^{* * *}$ and conductivity are measured online. The nitrate concentration, as well as $\mathrm{pH}(\mathrm{pD})$ and conductivity, are determined offline on grab samples.

Since the institution of moderator $\mathrm{pD}$ control, there have been only two occurrences of high turbidity, plus occasional periods of turbidities in the range 5 to $20 \mathrm{ppm}$ during the first few weeks of a reactor cycle. ${ }^{10}$ High turbidity occurred in the L-2 cycle in 1964 when ability to control pD by nitric acid was temporarily lost. It occurred again, though less severely, throughout most of the Cf I cycles in K-Reactor in 1970; these cycles were of a few days duration, so short that pD control of corrosion could not be esiablished.

\subsubsection{Chemical Aspects of oD Control ${ }^{8}$}

$\mathrm{pD}$ control was successful in minimizing aluminum corrosion and moderator turbidity problems, but it resulted in a system harder to monitor for tramp impurities. Moderator conductivity was increased from $<0.2$ to about $3 \mu \mathrm{S} / \mathrm{cm}$. The two online measurements, conducivity and $\mathrm{pH}$, are nonspecific and cannot identify what ions are present in the moderator. Offline analyses for nitrate and other anions such as chloride are necessary to confirn the chemical system and detect the presence of deleterious impurities such as chloride.

Also, a slight excess of oxygen had to be maintained in the moderator system because without it the reducing environment from corroding aluminum destroyed the nitric acid. In at least one instance nitrate was reduced to ammonia. Ammonia formation would ultimately result in an increase in $\mathrm{PD}$ and lead to increased aluminum corrosion. Dissolved oxygen at about $500 \mathrm{ppb} t$ is sufficient to ensure nitrate stability. It was recognized that the oxygen added should be minimized to avoid enhanced corrosion of stainless steel.

\subsubsection{Chemister Role in Stainless Steel Corresion}

The principal type of corrosion that has been found in the stainless steel of the primary system of the SRS reactors has been intergranular stress corrosion cracking (IGSCC). For IGSCC to occur, three factors must be simultaneously present:

susceptible (sensitized) material, applied and/or residual tensile stress, and an environment that can provide the chemical driving force for corrosive reaction. 11 Because the environment is the only one of the three conditions readily accessible for change, improvements in moderator and shield water chemistry were among the goals of the Reactor Materials Program.

***The measured $\mathrm{pH}$ is empirically converted to $\mathrm{pD}$ by adding 0.4 . tppb $=$ parts per billion (micrograms per liter) 
Coolant quality and its effect on corrosion in nuclear power reactors has been extensively considered. ${ }^{11}$ However, boiling water reactors operate at $288^{\circ} \mathrm{C}$, whereas the SRS reactors operate at only $-100^{\circ} \mathrm{C}$. A literature survey performed for the Reactor Materials Program revealed only limited SSC data in near-SRS

environments. ${ }^{12}$ The survey concluded that, although the presence of impurities in the low temperature environment of the SRS reactors was not considered particularly damaging, the effects of the oxidizing SRS environment with oxygen and peroxide present, should be investigated.

\subsubsection{Chemistry Role in Aluminum Churosion}

Acidification of the moderator to control alumina turbidity was based on knowledge that aluminum corrosion is reduced at $\mathrm{pH} \sim 5.13,14$ Exact conditions for SRS reactor moderator chemistry were established by extensive in-reactor testing during which the corrosinn rate $\left(D_{2}\right.$ evolution) was minimized. ${ }^{8}$

Nitric acid was chosen as the final acidifier because it was most suitable in terms of thermodynamic and radiolytic stability as well as minimal radioactivity problems arising from neutron activation. Carbon dioxide was also iried, but was abandoned because attendant high peroxide levels were considered undesirable for stainless steel corrosion. Phosphoric and sulfuric acids were rejected because of the formation of ${ }^{32} \mathrm{P}$ and ${ }^{35} \mathrm{~S}$, bioactive isotopes that might eventually enter the environment.

\subsection{Results from the Reactor Materials Program}

\subsubsection{Background}

The purpose of the Reactor Materials Program was to evaluate material performance in SRS reactor tanks and moderator piping, with the objectives of assessing reactor safety and predicting and extending reactor service life. ${ }^{1}$ The eleven tasks in the program are listed in Table 3 . Three of these tasks were concerned with corrosion and with chemistry of the moderator and shield water systerns. The results from each of these three tasks is summarized in this section. The results of these tasks form the foundation for improvernents in moderator and shield water chemistry discussed in the next section.

\subsubsection{Task 6: Aqueous Environment}

Analyze Impurities in All K-Reacior Aqueous Streams with OnLine Analyzer

Objective: Quantitatively measure impurities in all K-Reactor moderator and thermal shield water to identify variables for intergranular stress corrosion cracking of stainless steel (Task 7).

Routine sample analyses and special analysis programs provided the historical basis for defining moderator and shield wat 5 compositions. ${ }^{8.9}$ To supplement these data for the Reactor Materials Program, special sampling and analysis programs were 
carried out. 15,16 These provided supplementary information on impurity levels and demonstrated ion chromatography as a viable technique for moderator analysis. For the baseline data needed for corrosion tests (Task 7) and for real-time characterization of moderator impurity sources and sinks, online analyses were planned.

A customized online analyzer was built and demonstrated. 17 The analyzer was similar in design to those used to control and analyze the aqueous environment for the corrosion tests of Task 7. The online analyzer consisted of three ion chromatography systems to determine cations, anions and organic acids; an electrochemical system for peroxide; and a gas-stripping, infrared analy.er system for carbon dioxide. Chloride, nitrate, nitrite, sulfate, oxalate, lithium, sodium, potassium and ammonium ions could be determined at the 1 ppb level; organic acids could be determined to 5-10 ppb; hydrogen peroxide and carbon dioxide at $100 \mathrm{ppb}$.

The online analyzer was placed in a special facility in the -20 level of $K$-Reactor. From the sampling points shown in Figure 1, the heavy water moderator upstream and downstream of the deionizers, the light water shield water, and the deionized light water used for makeup in the thermal shields could all be circulated to the analyzer for analysis.

The analyzer was never connected to the reactor system because of anticipated problems with tritiated $\mathrm{D}_{2} \mathrm{O}$ leakage and lack of priority for the analyzer in the production schedule. The online data needed for the corrosion tests was therefore not generated, and the test environments for Task 7 were chosen based on the knowledge at hand. With current enhanced recognition of the importance of coolant chemistry in IGSCC mitigation, the necessary priority for installation of a secondgeneration analyzer may be found in the future.

\subsubsection{Task 7: Corrosion}

\section{Measure Effect of Moderator Chemistry on Stress Corrosion of Sensitized and of Irradiated Stainless Steel}

Objective: Define moderator chemistry to minimize IGSCC and measure crack growth rates.

The majority of information on initiation and propagation of IGSCC in Type 304 Stainless Steel has been developed in coujunction with studies of boiling water reactors. These reactors are different from SRS reactors both in operating conditions, particularly temperature, and aqueous constituents. The addition of nitric acid and oxygen is unique to SRS reactors, as is the presence of peroxide at part-per-million levels. Other impurities, such as chloride, sulfate, and dissolved carbon dioxide, are common to both production and power reactors.

\subsubsection{CERT Tests ${ }^{18}$}

Constant Extension Rate Tensile (CERT) tests were performed to evaluate the relative influence of water impurities and temperature on IGSCC of Type 304 stainiess steel and to provide guidance for moderator chemistry improvements. 
Samples for testing were made from pipe taken from the SRS R-Reactor, to ensure that the stainless steel tested would be representative of that in operating SRS reactors (vintage 1950's). The coupons were heat treated to simulate the heat affected zones of welds. Both unirradiated coupons and coupons irradiated in the ORNL High Flux Isotope Reactor to neutron fluence levels comparable to reactor tank walls were tested. The temperature and aqueous environment were maintained in ranges representative of SRS primary coolant anci shield water systems, as shown in Table 4

The tests consisted of a central composite statistical design with temperature, and hydrogen peroxide, oxygen, carbon dioxide, sulfate, and chloride concentrations as independent variables. 19 The logarithm of the adjusted time to maximum stress (LATMS) was chosen as the dependent variable signifying IGSCC. The variable included the time to maximum stress and ductility as measured by both elongation and reduction in area. As the LATMS increases, the possibility of IGSCC decreases, i.e. large values of LATMS are desirable. The tests revealed that the significant independent variables that contributed to IGSCC were, in the order of their decreasing importance: temperature, chloride, temperature-and-sulfate, chlorideand-chloride, chloride-and-sulfate. The presence of peroxide was significant, except at chloride concentrations at or below $8 \mathrm{ppb}$.

The product from the tests was an equation that sums the effect of each impurity on IGSCC. This equation has been used to predict effects of impurity levels and to specify remedial conditions. Table 5 presents the equation and examples of its application.

\subsubsection{Crack Growth Tests 20}

Crack growth experiments were performed with coupons made from the unirradiated $R$-reactor stainless steel and present-day Type 304 Stainless Steel. The coupons were heat treated to simulate the heat affected zones of welds, fatigue precracked, then environmentally precracked to produce an IGSCC crack.

The precracked coupons were tested at various stress intensities, under constant and transient loads, at 80 to $120^{\circ} \mathrm{C}$ in synthetic moderator environments. Environments were designated low, nominal, high, and improved, as shown in Table 6 . Control and analysis of the environment was supplied by the loop and analyzer system used for the CERT tests. Crack growth measurements were made by the reversing DC potential method.

A wide range of crack velocities $\left(10^{-7}\right.$ to $10^{-4}$ inch/hour) was observed. These results compare favorably with a high-confidence crack growth rate of $4 \times 10^{-5}$ inch/hour, that was deviloped reflecting laboratory, literature, and SRS reactor ultrasonic inspection. 21 This crack growth rate is used as the conservative choice for pipe cracking calculations.

In the crack growth tests, systematic changes in temperature and environments did not always produce systematic changes in crack growth rates. Incremental growth occurred during test perturbations and caused $62 \%$ of the crack growth in $4 \%$ of the test time under constant load. 


\subsubsection{Task 10: Electrochemical Potential 22}

Measure Mederater Elecurechemical Potenuial

Objective: Provide data to interpret the corrosion results and correlate laboratory lests to SRS reactor moderator environment.

Electrochemical potential (ECP) measurements provide information about the chemical or electrochemical driving force for IGSCC. ECP is used in the nuclear power industry as an indicator for detecting conditions above the threshold potential of -230 millivolts(SHE)*, where IGSCC may occur. The lower temperatures of the SRS reactors $\left(-100^{\circ}\right.$ versus $\left.288^{\circ} \mathrm{C}\right)$ provide a higher ECP threshold for IGSCC cracking. However, both the added oxygen and the peroxide present in the SRS system are expected to increase the ECP.

Inline measurements of electrochemical potentials of both platinum and Type 304 stainless steel were made in K-Reactor moderator for about a year during 1986-7. Electrodes were placed in the hot leg of the "corrosion loop". shown in Figure 1. Here measurements could be made upstream of the heat exchangers and in moderator only a few seconds out of the reactor tank. Continuous data were collected during all phases of reactor operation.

As expected, the potentials indicated an oxidizing system. The potentials ranged from 400 to $600 \mathrm{mV}$ (SHE) for stainless steel and from 200 to $400 \mathrm{mV}$ (SHE) for platinum. The observed potentials were in agreement with values observed during the CERT tests in Task 7. Observed potentials were several hundred millivolts higher than the ECP threshold recommended for power reactors. However, data from the literature indicate that these higher potentials would be marginal in promoting IGSCC at the relatively low operating temperatures of the SRP reactors. The literature data implies that if it were possible to lower the potential of the stainless steel a few hundred millivolts, the steel would stop cracking.

\subsection{Application of Results}

\subsubsection{General Comments}

Results from the Reactor Materials Program have confirmed that current SRS moderator and shield water limits provide an environment that is relatively benign with respect to IGSCC. Certain improvements can be made, and some improvements recommended have already been implemented. Current moderator and shield water limits are given in Table 7. Sampling frequency for routine samples is given in Table 8.

The Systems Chemistry Group of the Reactor Engineering Department has recently addressed in depth the technical bases and adequacy of methods, systems, procedures, requirements, and administrative controls currently used at SRS to maintain, control, monitor, analyze, and record moderator quality during all phases of plant operation and layup. 23 This section supplements the Reactor Engineering documentation and defines areas for improvement that the Reactor Materials Program has identified.

* SHE designates potential versus the Standard Hydrogen Electrode. 


\subsubsection{Moderator}

Operating limits (Table 7) for moderator quality address the following: pD control, oxygen control, radiolysis, stainless steel and aluminum corrosion. impurity control. and mode of reactor operation. Limits during wet layup and shutdowns have been addressed and specified to be similar to those during reactor operation in order 10 avoid chemical shock to the system.24,25

\subsubsection{1 pD Control}

Low lurbidity and low aluminum corrosion in the SRS reactors have been successfully maintained for about 30 years with $\mathrm{pD}$ control by nitric acid addition. Little or no IGSCC of the stainless steel system has developed for many years 26 The reactor system is "seasoned" to this chemistry. Current operating limits for conductivity, $\mathrm{pD}$, and nitrate content are adequate.

Becommendacion that ne changes in the fundamensal speration with nitric acid and excess exygen be made.

\subsubsection{2 pD Limits}

Current limits and standards recognize that a change of $\mathrm{pH}(\mathrm{pD})$ in either direction will increase corrosion of aluminum. Recently another factor in the standards was addressed, namely that the pH must never be high enough to cause precipitation of gadolinium hydroxide after injection of gadolinium nitrate from the supplementary Saiety Systern. This recommendation is included in Table 7.

\section{Becommendation: that undated of limits in Table 2 remaia unchanged}

\subsubsection{Oxygen Control}

Extrapolation of ECP values measured in $\mathrm{K}$-moderator indicared that at $100^{\circ} \mathrm{C}$ conditions are marginal for IGSCC in an oxygenated system. Hence operation with the minimum dissolved oxygen concentration in the moderator, consistent with nitrate stabilizy, is prudent. Continuing surveillance of oxygen concentration, plus an experimentally established minimum oxygen concentration would provide defensible oxygen concentration limits for reactor operation.

Becommendation: thas reliable online monitors for exygen be maintained and that the minimum exyaen cencentration necessary te ensure nitrate stabilivy be deiermined expecimentally enline during ieacier eperation.

\subsubsection{Kadlolysis}

Some radiolytic decomposition of the moderator is inevitable because of the high radiation field during operation and of the high residual gamma dose from activation products in the tank wall during shutdown. Maintaining low concentrations of dissolved material in the moderator minimizes radiolytic decomposition.

Principal radiolytic products in the SRS reactors are deuterium and deuterium peroxide. Deuterium from radiolysis is indistinguishable from the larger amounts released from the corrosion of aluminum in the heavy water during reactor 
operation. Table 1 shows that peroxide is a major constituent indigenous to the moderator. Historically, peroxide has tracked the oxygen concentration in the system. ${ }^{8}$ The CERT tests showed that the presence of peroxide increased the ECP of the stainless steel. Also, peroxide generally enhanced IGSCC.

Recommendacion. that exlcaneous dissolyed impurities beyond the nitric arid and oxygen needed for oD conirol be eliminated.

\subsubsection{Impurity Control}

The CERT tests have provided specific recommendations for impurity level limits. The tests revealed a dependence of IGSCC on temperature, chloride, temperature-sulfate. chloride-sulfate, and chloride-chloride. The tests revealed the need for knowledge and control of chloride and sulfate at concentrations $<10 \mathrm{ppb}$. For example, at chloride concentrations below 8 ppo the effect of peroxide on IGSCC was eliminated.

A step toward improvement of control has been recently made by Analytical Laboratories ${ }^{27}$ in lowering respective analytical sensitivities of chloride and sulfate to 1 and $7 \mathrm{ppb} \pm 25 \%$. This will enable realistic trending of these impurities in the levels of interest.

Becommentation: that shloride and sulfate ion cor sentrations be reduced to 2 and 7 pob respectively.

More fundamental is identificarion and elimination of sources of chloride and sulfate. lon exchangers are major potential soures of both chloride and sulfate. The anion exchange resins are manufaciured in the chloride form and are then exhaustively treated to remove the chloride; the cation exchange resins contain sulfonic acid ion exchange sites. While in theory the use of a mixed bed should result in removal of all ionic material. some leakage of impurities may occur. Other sources of impurities are materials in contact with the moderator that contain leachable chlorides and sulfates.

Recommendation: that ion exchange resins and practices be reevaluated.

Recommendation: that porential sources of chloride and sulfate such as filler and gaskel materials be replaced with lower source materials where possiuls.

Improved control of moderator quality is contingent upon timely information about impurity trends. As shown in Table 7 , current routine sampling for identification of impurity parameters occurs only once a week. Only conductivity, $\mathrm{pH}(\mathrm{pD})$, and oxygen are measured online. Additional online capabilities would not only ensure better control of moderator quality but also eliminate radiation doses and hazards inherent in sampling, transport, and offline analysis.

Recommendation: that sampling frequency be increased as practicali_in particular. during periods of charge and discharge when the sysiem can receive impurities from outside sources. sampling should be increased 10 ance a day.

Becommendation: thu additional online sensors such as for chloride and sulfase be installed and that witimately a second generation multioumose online analyzer bs evaluated and installed. 


\subsubsection{Mode of Reactor Operation}

In addition to the chemical environment, physical conditions during reactor operation can contribute to crack propagation and/or growth in stainless steel. Obviously changes in physical operation are not always possible, but recommendations about reactor operation stemming from the Reactor Materials Program are included for completeness.

The CERT tests have shown, not surprisingly, that temperature is by far the most importani independent tariable in promoting IGSCC. The obvious solution, then, is 10 reduce the temperature. In Table 5, where the CERT equation is evaluated for various conditions, it is seen that operation at lower temperature with nominal SRS impurities would be as effective in mitigating IGSCC as a 3-to 5-fold reduction in the already low nominal chloride and sulfate concentrations.

\section{Recommendation: that the beneficial effect of reduced eperating temperatures in mitigating IGSCC be recognized.}

In the crack growth tests, mosi of the crack growth occurred during transients, such as a temperature change in the system. The physical shock accompanying such transients was postulated as contributing to crack growth through slip step emergence due to strain, with protective film rupture. Minimizing transient conditions would hence minimize propagation of existing cracks.

Recommendation: that during reactor operation. effors be made to reduce reactor scrams or oher ragid thermal or load changes.

\subsubsection{Shield Water}

Shield water limits allow higher concentrations of impurities than do those for moderator, as seen in Table 7 . The $\mathrm{pH}$ is not as critical because no aluminum is present, and the higher concentrations are of less concern because the temperature is lower. The CERT test equation was applied to shield water conditions in Table 5 . It is evident that satisfactory protection from IGSCC can be attained from either reducing the temperature or reducing the level of impurities. ${ }^{7.18}$ Cooling would put too large a stress on the vessel T-Weld.

Recommendation that the shield water be deionized to lower chloride ion sencentration to $5 \mathrm{pob}$ and sulfate to 7 pob. 


\section{REFERENCES}

1. N. G. Awadalla, G. R. Caskey and R. S. Ondrejcin, Eds., Reactor Materials Program, DPST-84-820 (December 1984).

2. SRS Production Reactor SAR WSRC-SAR-RX-PLK, Table 4.1-1.

3. SRS Production Reactor SAR WSRC-SAR-RX-PL.K, 5.1.1.1.

4. Drawings:

W133620: Top Tube Sheet Chimes, Plan Sections and Chimes W133629: Top Tube Sheet, Plan and Cross Section, Arrangement W133942: Annular Cooling Tanks, Plan and Sections, Arrangement W134318: Main Tank Assembly; Cross Section, Arrangement W133998: Annular Cooling Tank, Iron Ring, Plans and Sections W133389: Tank Botrom Tube Sheet, Plan and Cross Section, Arrangement W132762: Tank Bottom Tube Sheet, Sections and Details Sheet 1. Arrangement

5. DPSOL 105-1106 Graphic Panel Data Sheet (5/22/90).

6. DPE-913, Maximum Permissible Stresses and Deformation In Reactors and Thermal Shields (Secret) (5/8/56).

7. R. S. Ondrejcin and M. H. Anderson, Moderator and Shield Water Chemistry (U) SRL-MTS-900146. (June 18, 1990).

8. F. B. Longtin, Reactor Chemistry and Radioactivity Manual, RTR-1806 (August 9 , 1978).

9. Sample Analysis Schedule and Control-Routine DPSOL 105-6101A-PLK, Revision $11 .(5 / 11 / 89)$.

10. E. W. Baumann, Turbidity Levels in SRP Reactors 1958-1987, DPST-87-88\%, (December 30, 1987).

11. Metals Handbook, 9th Ed, Volume 13, Corrosion; p. 927, J. C. Danko, "Corrosion in the Nuclear Power Industry", ASM International, Metals Park, OH (1987).

12. B. M. Gordon and H. S. Mehta, Stress Corrosion Cracking Literature Review and Analysis for the Savannah River Plant, NEDC-30837, General Electric Co., San Jose, CA (December 1984).

13. J. E. Draley and W. E. Ruther, Aqueous Corrosion of Aluminum, Corrosion 12, $441 t$ (1956).

14. E. Deltombe and M. Pourbaix, The Electrochemical Behavior of Aluminum, Corrosion, 14, 496t-500t (1958). 
15. E. W Baumann, Analysis of Moderator and Thermal Shield Water for Reactor Materials Program, DPST-84-963 (December 20, 1984).

16. E. W. Baumann, Analysis of Aqueous Systems of SRP Reactors by Ion Chromatography for the Reac'or Matcrials Program, DPST-86-282 (February 24. 1986).

17. R. S. Ondrejcin and E. W. Baumann, "An On-line Analyzer for K Reactor (U)", WSRC-TR-90-565 (December 1990), to be issued.

18. R. S. Ondrejcin and G. R. Caskey, Assessment of Susceptibility of Type 304 Stainless Steel to Intergranular Stress Corrosion Cracking in Simulated Savannah River Reactor Environment (U), WSRC-RP-89-1230 (December 1 , 1989).

19. R. S. Ondrejcin, G. R. Caskey, P. Aldred and S. A. Wilson, Aqueous Impurity Effects on Stainless Steel IGSCC: A Central Composite Matrix Analysis, Corrosion 89, Paper \#505, New Orleans, LA, April 17-21, 1989.

20. G. R. Caskey, R. S. Ondrejcin and K. J. Stoner, Growth of Stress Corrosion Cracks in Type 304 Stainless Steel Under Savannah River Environmental Condition, in preparation.

21. K. J. Stoner, G. R. Caskey, and W. L. Daugherty, Reactor Materials Program - A Derivation of Nominal IGSCC Growth Rate for SRS Reactors (U) WSRC-RP-90-9: (March 1, 1990).

22. E. W. Baumann and R. S. Ondrejcin, Electrochemical Potentials of Stainless Steel and Platinum in $\mathrm{K}$ Reactor Moderator, DPST-88-621 (July 6, 1988).

23. L. V. DeWitt, A. Gibbs, D. P. Lamber, S. R. Bohrer, R. L. Fanning, M. W. Houston, S. L. Stinson, R. W. Deible, and S. I. Abdel-Khalik. Moderator Chemistry Program (U), WSRC-TR-90-42-125, in preparation.

24. E. W. Baumann for Reactor Corrosion Mitigation Committee, Guidelines for Corrosion Mitigation During Protracted Reactor Shutdowns (U), WSRC-RP-891023 (Oclober 9. 1989).

25. D. P. Lambert to R. P. Taylor, K Reactor Moderator Cliemistry Limits, OPS-RTD0283 (October 18, 1989).

26. G. R. Caskey, K. E. Kehr, M. H. Hilker, D. E. Rawl and R. F. Mittelberg. Leak History, Reactor Primary Coolant Systems (U), WSRC-RP-89-126 (April 21, 1989).

27. G. D. Levi, Jr., Trace Anion Improvements, ESH-AL-901071 (July 2, 1990).

28. E. W. Baumann, Reactions of Hydrogen Peroxide and Ion Exchange Resins, DP477 (April 1960).

29. 105-Building Technical Standards DPSTS-105-2.7 (April 1, 1975). 
TABLE

\section{PRINCIPAL DISSOLVED CONSTITUENTS IN MODERATOR}

\begin{tabular}{|c|c|c|c|}
\hline Solute & Source & Sink & $\begin{array}{c}\text { Concentration, } \\
\mathrm{pDb}^{\mathrm{a}} \\
\end{array}$ \\
\hline Oxygen $\left(\mathrm{O}_{2}\right)$ & $\begin{array}{l}\text { Added } \\
\text { Reaction of } \mathrm{D}_{2} \mathrm{O}_{2} \\
\text { and deionizer resin }\end{array}$ & $\begin{array}{l}\text { Reaction with } D_{2} \\
\text { Reaction with organics }\end{array}$ & $500-2000$ \\
\hline Peroxide $\left(D_{2} O_{2}\right)$ & Radiolysis of $D_{2} O$ & $\begin{array}{l}\text { Reaction with deionizer } \\
\text { resin } 28\end{array}$ & $500-2000$ \\
\hline Deuterium $\left(D_{2}\right)$ & $\begin{array}{l}\text { Corrosion of } \mathrm{Al} \\
\text { Radiolysis of } \mathrm{D}_{2} \mathrm{O}\end{array}$ & $\begin{array}{l}\text { Reduction of nitrate } \\
\text { Reaction with oxygen } \\
\text { Escape into blanket gas }\end{array}$ & 900 (estimate) \\
\hline $\begin{array}{l}\text { Nitric Acid } \\
\left(\mathrm{DNO}_{3}\right)\end{array}$ & Added for $\mathrm{pD}$ control & $\begin{array}{l}\text { Reduction by } D_{2} \\
\text { Reduction by organics } \\
\text { Removal by deionizers }\end{array}$ & 600 \\
\hline $\begin{array}{l}\text { Carbon Dioxide } \\
\left(\mathrm{CO}_{2}\right)\end{array}$ & $\begin{array}{l}\text { Oxidation of } \\
\text { organics by } \mathrm{O}_{2} \text {. } \\
\mathrm{D}_{2} \mathrm{O}_{2} \text { or } \mathrm{NO}_{3}^{-}\end{array}$ & $\begin{array}{l}\text { Removal by deionizers } \\
\text { Escape into blanket gas }\end{array}$ & $200-400$ \\
\hline Sulfate $\left(\mathrm{SO}_{4}{ }^{2-}\right)$ & $\begin{array}{l}\text { Cation exchange } \\
\text { resin degradation }\end{array}$ & Removal by deionizers & 50 \\
\hline Chloride $\left(\mathrm{Cl}^{-}\right)$ & $\begin{array}{l}\text { Ubiquitous } \\
\text { Anion exchange } \\
\text { resin }\end{array}$ & Removal by deionizers & 10 \\
\hline Organics (C) & $\begin{array}{l}\text { Degradation of } \\
\text { deionizer resins }\end{array}$ & Oxidation by $\mathrm{O}_{2}$ or $\mathrm{D}_{2} \mathrm{O}_{2}$ & not determined \\
\hline
\end{tabular}


TABLE 2

\section{DISSOLVED CONSTITUENTS IN THERMAL SHIELD WATER 15,16 [OBSERVED RANGE IN PLKC REACTORS]}

Len

Chloride $\left(\mathrm{Cl}^{-}\right)$

Nitrate $\left(\mathrm{NO}_{3}^{-}\right)$

Nitrite $\left(\mathrm{NO}_{2}^{-}\right)$

Sulfate $\left(\mathrm{SO}_{4}{ }^{2-}\right)$

Sodium $\left(\mathrm{Na}^{+}\right)$

Potassium $\left(\mathrm{K}^{+}\right)$

Ammonium $\left(\mathrm{NH}_{4}{ }^{+}\right)$

Peroxide $\left(D_{2} O_{2}\right)$

${ }^{a} p p b=$ parts fer billion (micrograms per liter)

\author{
Concentration Range. $\mathrm{Ppb}^{\mathrm{a}}$
}

$20-250$

$<50-3100$

$<10-40$

$230-1850$

$<10-1600$

$<10-230$

$<10$

$<500 \cdot 3000$ 
TABLE 3

TASKS OF THE REACTOR MATERIALS PROGRAM

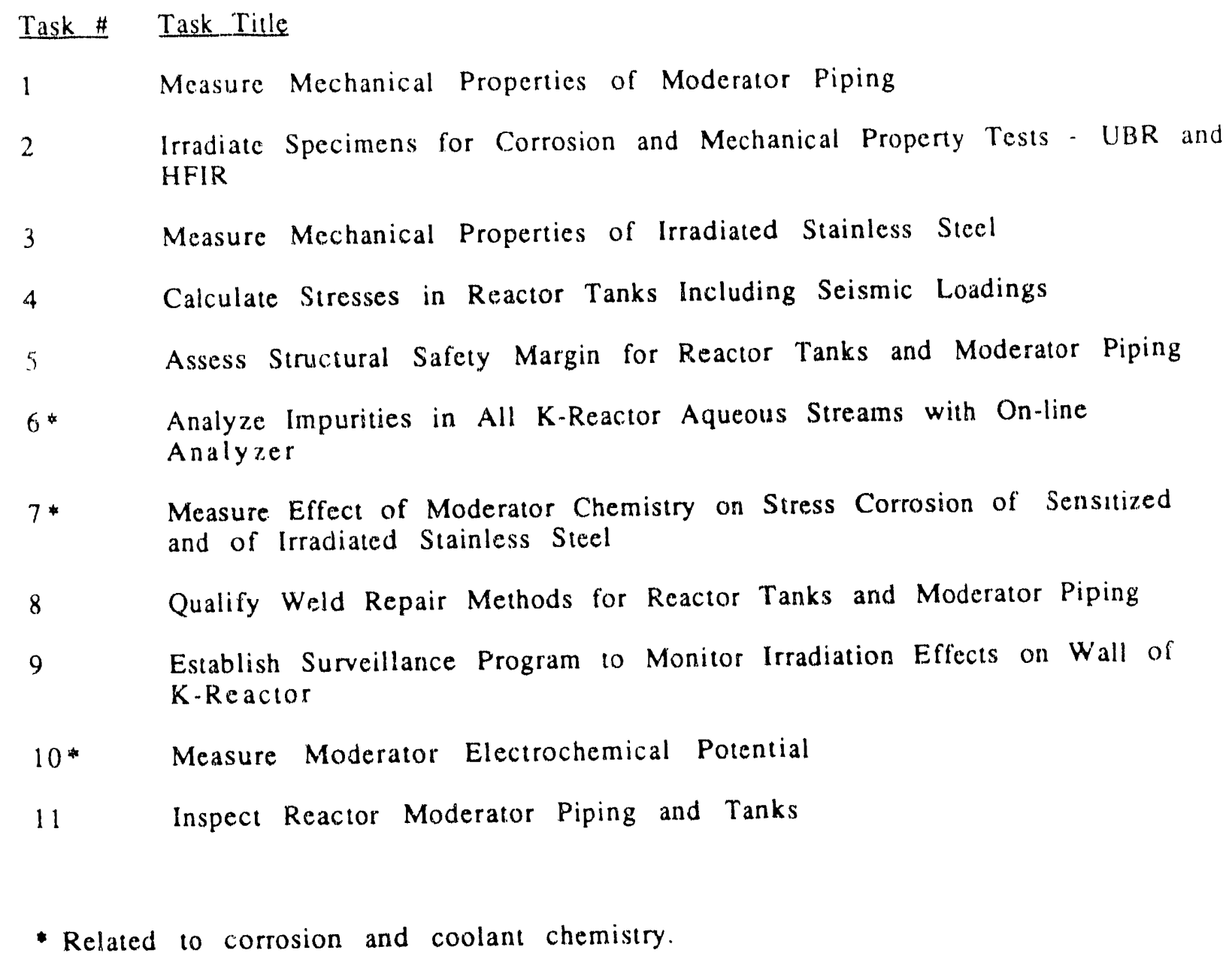

- Related to corrosion and coolant chemistry. 
TABLE 4

\section{CONCENTRATION RANGES OF INDEPENDENT VARIABLES*}

$\frac{\text { Variable }}{\text { Temperature, }}$

Chloride, ppb

Sulfate, $p p b$

Carbon Dioxide, ppb

Hydrogen Peroxide, ppb

Oxygen, ppb (either added or from peroxide decomposition)

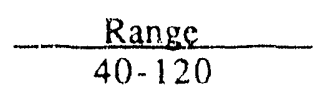

$$
2-100
$$

$7-500$

$20-1000$

$400-5000$

$100-8000$

*Nitric acid added to maintain $\mathrm{pH}$ at $5.1 \pm 0.2$; light water was used as a stand-in for heavy water. 
TABLE 5

\section{EVAI,UATION OF MODERATOR AND SHIELD WATER CONDITIONS FROM} CERT TESTS

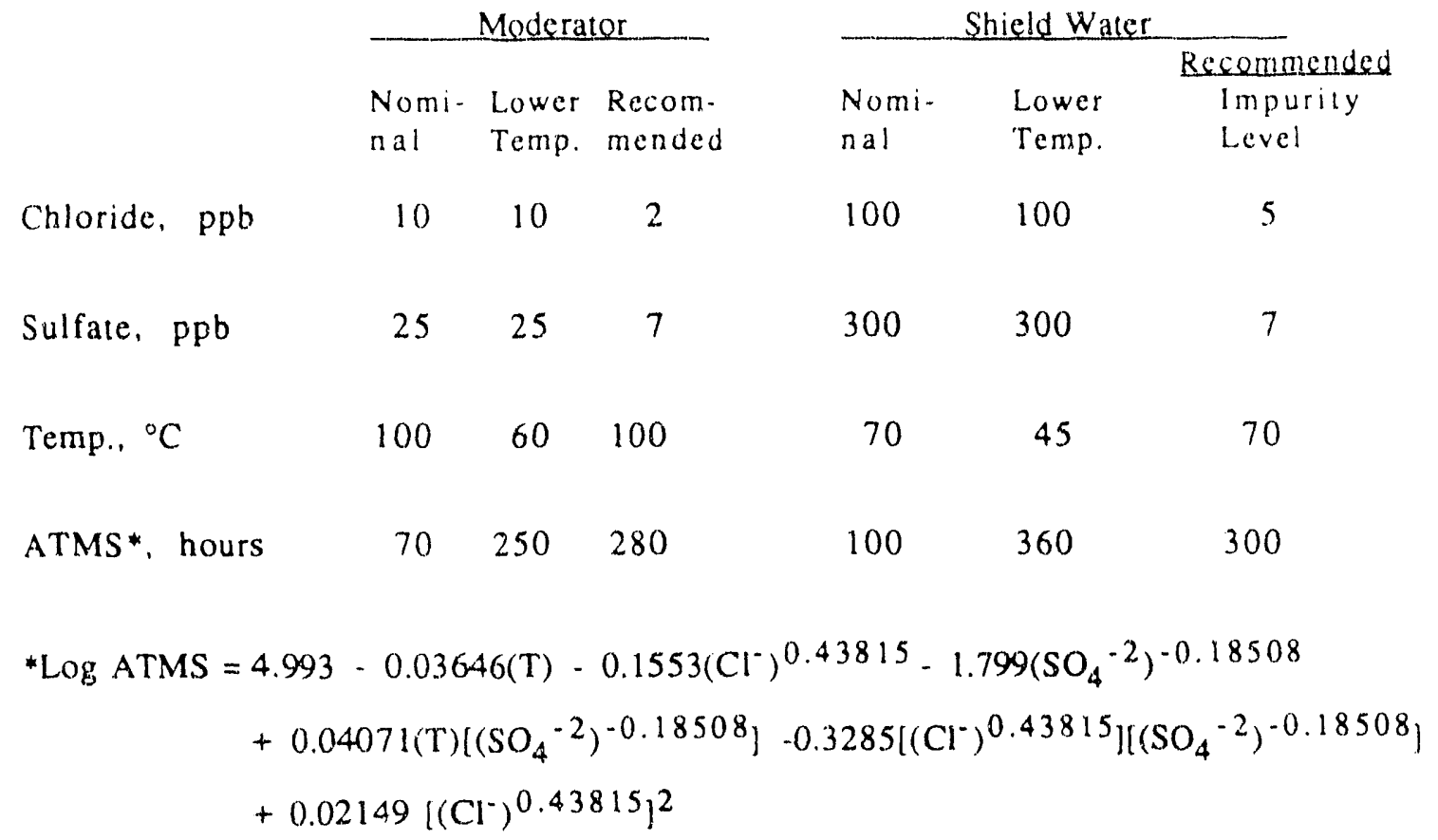

where $\mathrm{Cl}^{-}$and $\mathrm{SO}_{4}^{-2}$ are in $\mathrm{ppb}$ and $\mathrm{T}$ is temperature in ${ }^{\circ} \mathrm{C}$. 
TABLE 6

\section{SYNTHETIC MODERATOR ENVIRONMENTS FOR CRACK GROWTH TESTS}

$\begin{array}{lcc}\text { Designation } & \text { Chloride } & \text { Concentration, } \\ \text { Low } & 2 & \text { Spblfate } \\ \text { Nominal } & 30 & 10 \\ \text { High } & 100 & 50 \\ \text { Improved } & 5 & 10\end{array}$

Note: Nitric acid was maintained to control pH at $5.1 \pm 0.2$; Carbon dioxide was held at $300 \mathrm{ppb}$. The oxygen from peroxide decomposition varied from 600-1600 ppb depending on the degree of decomposition. Light water was used as a stand-in for heavy water. 
TABLE 7

\section{TECHNICAL STANDARDS AND OPERATING LIMITS}

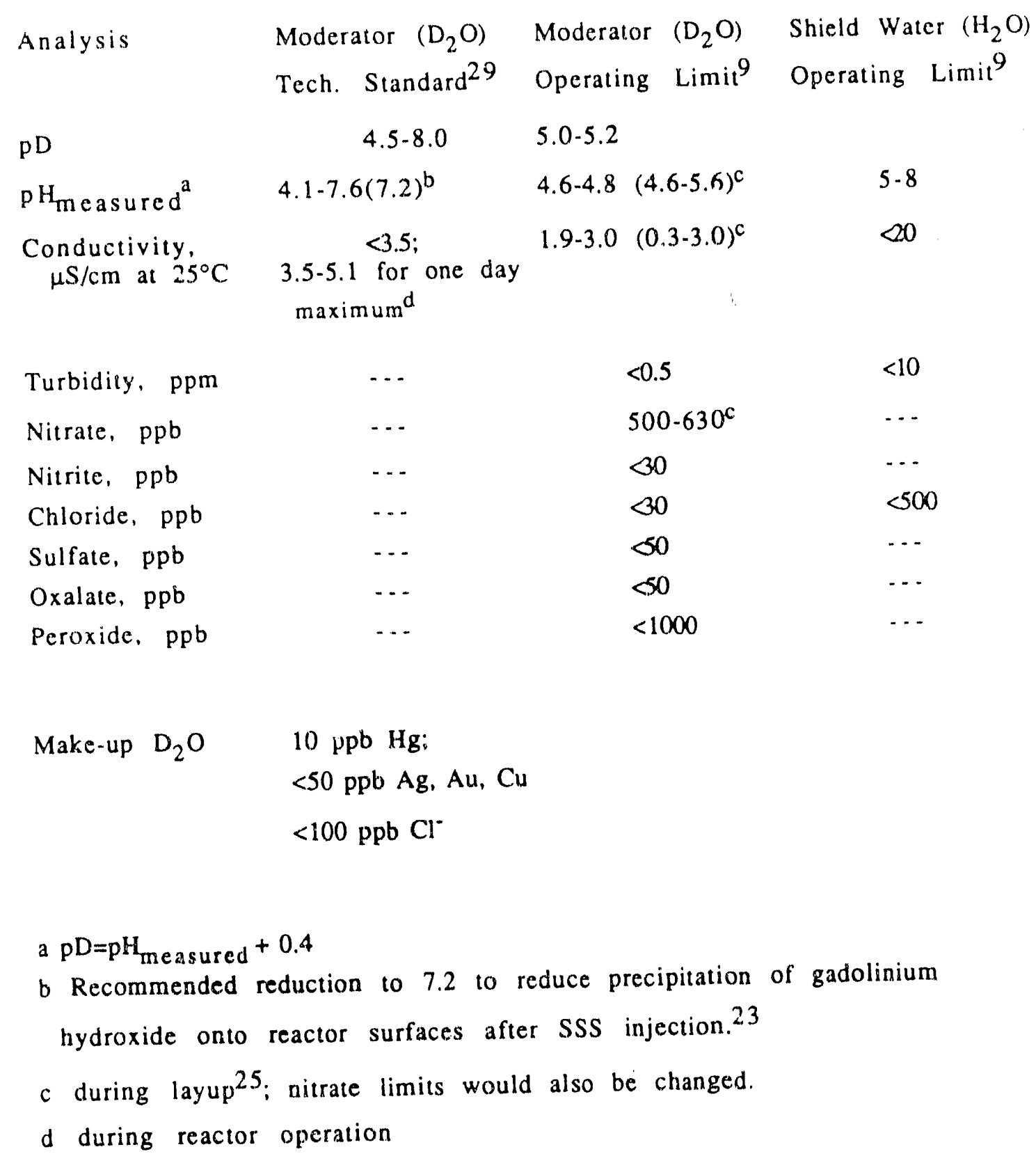


TABLE 8

SAMPLING FREQUENCIES ${ }^{9}$

\begin{tabular}{ll}
\multicolumn{2}{c}{ MODERATOR } \\
\hline From RX to \\
Purification & From Purifi- \\
& cation to RX
\end{tabular}

Shield Water

ANALYSIS

\begin{tabular}{|c|c|c|c|}
\hline Turbidity & $3 /$ week & $2 /$ we ek & $1 /$ week \\
\hline Alpha & $3 /$ we ek & $2 /$ we ek & $\cdots$ \\
\hline 2-hr Beta-Gamma & $3 /$ week & $2 /$ we ek & $1 / \mathrm{month}$ \\
\hline Conductivity & $1 /$ week & $1 /$ week & I/ we ek \\
\hline $\mathrm{pH}$ & $1 /$ week & $1 /$ week & $1 /$ we ek \\
\hline Nitrate & $1 /$ week & $1 /$ week & $\cdots$ \\
\hline Nitrite & l/week & $1 /$ we ek & $\cdots$ \\
\hline Chloride & $1 /$ we ek & $1 /$ week & $\cdots$ \\
\hline Sulfate (new) & $1 /$ we ek & $1 /$ we ek. & $\cdots$ \\
\hline Oxalate (new) & 1/week & $\cdots$ & 1/week \\
\hline Peroxide & $1 /$ week & $4 /$ week & $\cdots$ \\
\hline Radio.zuclides & 1/week & $\cdots$ & $\cdots$ \\
\hline Tritium & $2 /$ month & $\cdots$ & $\cdots$ \\
\hline Radionuclides & ' 'week & $\cdots$ & $\cdots$ \\
\hline Metal Content & $4 /$ year & $\cdots$ & $\cdots$ \\
\hline$S-35, P-32$ & as required & $\cdots$ & $\cdots$ \\
\hline $\mathrm{Na}-24, \mathrm{Cr}-51, \mathrm{Co}-60$ & & $\cdots$ & $4 /$ ye ar \\
\hline
\end{tabular}




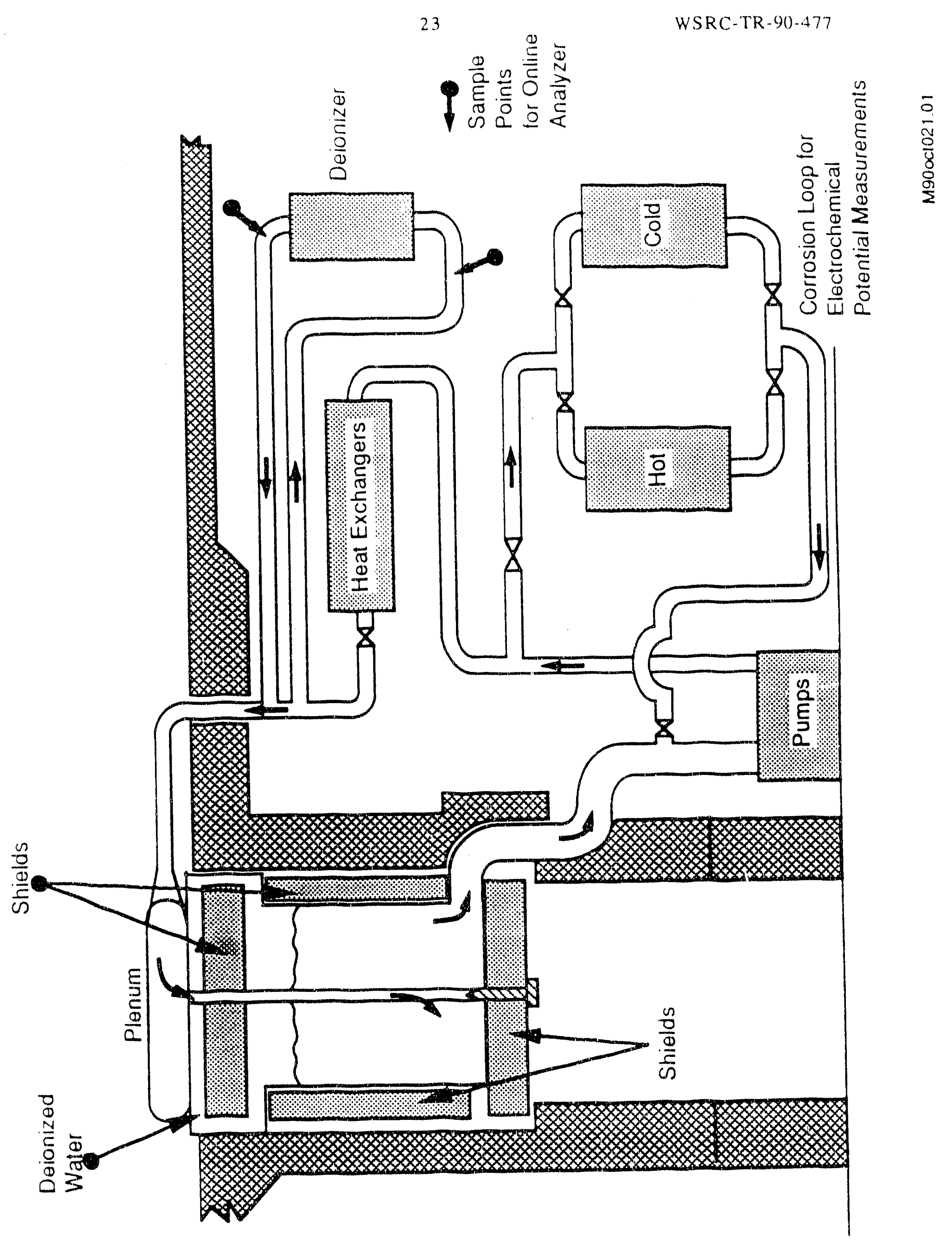

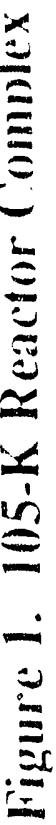


空
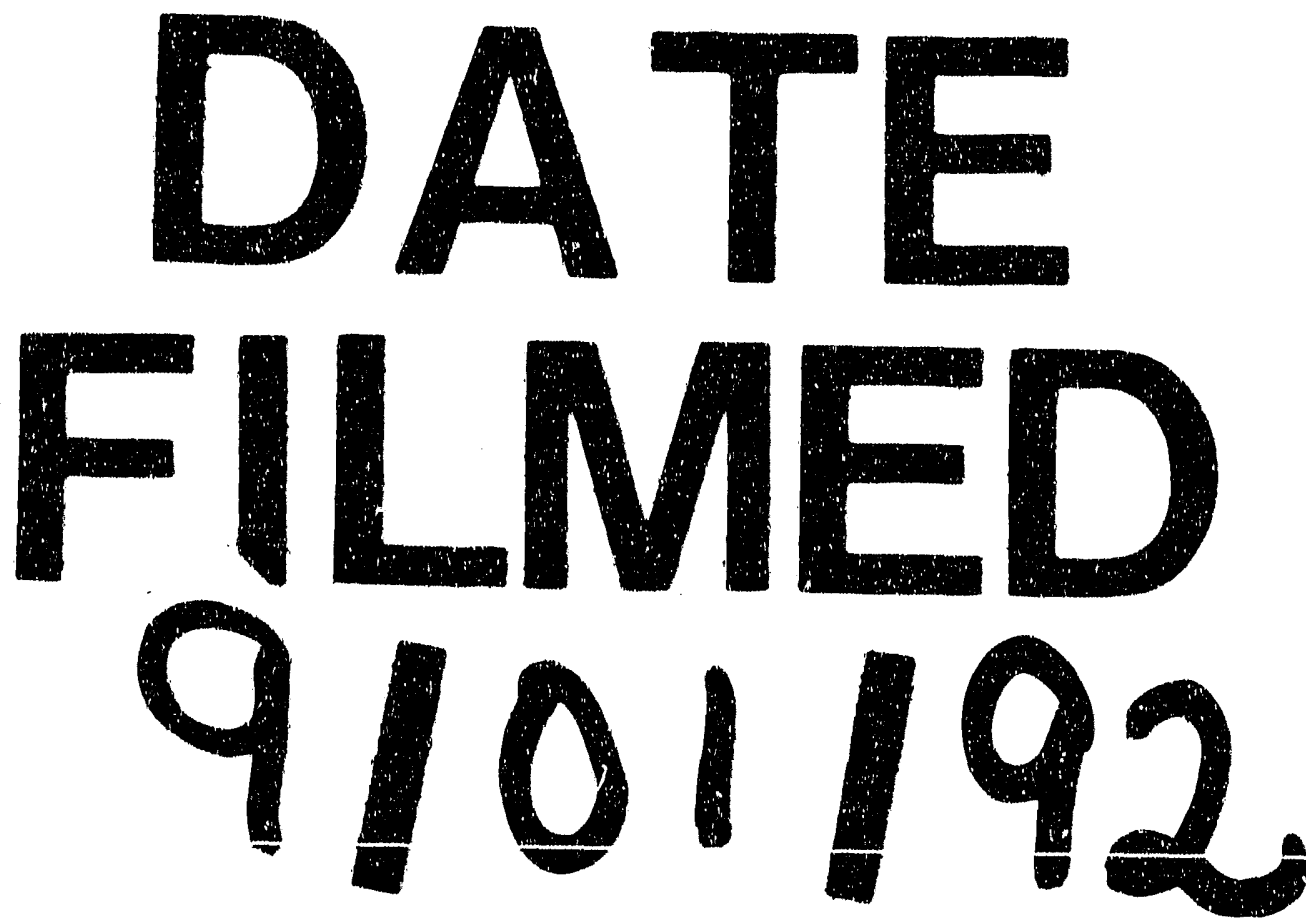
